\title{
Effcts of the herbicide gallant and mercury on liver function of Tilapia zilli
}

\author{
Abdel-Salam Mohamed Ibraik Ohaida \\ Zoology Department, Faculty of Science, $7^{\text {th }}$ of October University, Misurata, Libya.
}

\begin{abstract}
Background: Herbicides are highly toxic for both human and animal health. The increased application of herbicides in agriculture during the last decades has resulted in the contamination of both soil and water. Also do heavy metals, which represent one of the most important group of pollutants produced as a result of many industrial activities which can find their way easily to the normal aquatic environments, disturbing and damaging the existing organisms.

Material and Methods: Fishes of the species Tilapia zillii were exposed to sublethal concentration of herbicide Gallant (haloxyfop-ethopxy ethanol ester) $(3 \mathrm{mg} / \mathrm{L})$, mercury as mercuric chloride $(6 \mathrm{mg} / \mathrm{L})$ and a combined dose of herbicide $(1.5 \mathrm{mg} / \mathrm{L})$ and mercury $(3 \mathrm{mg} / \mathrm{L})$ for $96 \mathrm{hrs}$., in aquaria under controlled laboratory conditions. A comparative physiological study was carried out to test the toxicological effects of these pollutants on glutamic pyruvic transaminase (GPT), glutamic oxaloacetic transaminase (GOT) activities \& hepatosomatic index of liver.
\end{abstract}

Results: A progressive decrease in enzyme activity as well as total protein content of liver were observed, while hepatosomatic index showed a slight insignificant increase.

Key words: Gallant, mercury, glutamic pyruvic transaminase \& glutamic oxaloacetic transaminase activities and hepatosomatic index of liver.

\section{Introduction}

Modern agricultural practices in USA and many other countries have resulted in nearly unrivaled efficiency and productivity of pesticides and herbicides. Unfortunately, there is also the potential for release of these compounds to the environment and consequent adverse effects on wildlife and human populations (Dalton and Frick, 2008).

Numerous herbicides are now widely used in many parts of Egypt to control wide variety of grass. Gallant is active against a very wide range of grass weeds. Many of the treated areas contain fresh water resources like streams, lakes and ponds which harbour diverse aquatic fauna and flora.

Pollution by mercury represents a serious problem in the framework of chemical pollution of aquatic environment due to its high ability to accumulate in fish organs (Portmann, 1972; Scott and Armstrong, 1972 and Saleh, 1982) and subsequently may affect the people who feed on fish.
Numerous environmental pollutants including herbicides, fungicides, rodenticides, pesticides (organochlorine, organophosphorus, carbamate and pyrethroid ) as well as heavy metals, have been reported to alter liver function (Cashman, 1990; Riviere et al., 1990 and Saleh et al., 1991).

Intensive studies concerning the toxic effects of herbicide gallant on fish organs are lacking. Therefore, the present study was undertaken to elucidate the deleterious effects of herbicide gallant, mercury and a combined dose of both gallant and mercury on liver function of the Tilapia zillii.

\section{Material and methods}

\section{Experimental animals}

Tilapia zillii fishes weighing $\sim 36 \mathrm{~g}$ were obtained from Tawarga pond and transported immediately to adequate laboratory conditions (temperature $24 \pm 1$ ${ }^{\circ} \mathrm{C} \& \mathrm{pH}$ 7.5) for at least two weeks in 60 liters glass aquaria. 
Preliminary toxicity tests were conducted in the laboratory under static conditions.

\section{Chemical pollutants}

1- Gallant, which is a formulated herbicide, was purchased from Dow Chemical Company, Midland, Michigan, USA. It contains the active ingredient 2-ethoxyethyl, 2-[4-(3chloro-5-trifluoromethyl-2-

pyridyloxy) phenoxy]-propionate ; known by the common name haloxyfopethoxyethyl ester or haloxyfop-EE. Code Name Dow Co. 453.

2- Mercury as mercuric chloride was purchased from Dow chemical Company, Midland, Michigan, USA.

3- All other chemicals and reagents were of analytical grade.

\section{Expermintal protocol}

Fishes were divided randomly into four groups, 36 fishes for each. The first group was kept in fresh untreated Tawarga pond's water and used as control. The second group was exposed to a sublethal dose of herbicide gallant $(3 \mathrm{mg} / \mathrm{L})$. The third one was treated with a sublethal dose of mercury $6 \mathrm{mg} \mathrm{HgCl}_{2} / \mathrm{L}$ ). A combination of half sublethal doses of the above pollutants was performed for the fourth group.

\section{Sampling and tissue extract}

Batches of 6 fishes form each group were taken, dissected at intervals of 6,12 , 24, 48, 72 and 96 hrs. postinitial exposure. Representative samples of liver were immediately removed, homogenized in distilled water to make $10 \%$ homogenate (W/V) and kept in deep freezer at $-40 . \mathrm{C}$ till subsequent biochemical analysis.

\section{Methods}

The method used for the determination of GPT \& GOT was that described by Sabath et al., (1968). Total protein content was determined according to the method of Cabib and Polacheck (1984). The gutted weight of every fish was recorded. Its liver was removed and weighed. Finally, the hepatosomatic index (HSI) was calculated by the following equation formulated by Jangaard, 1967.

$\mathrm{HSI}=\mathrm{Wt}$ of liver in gram $\times$ 100/Gutted Wt of fish in gram.

\section{Statistical analysis}

The data were statistically analyzed using the t-test (Parker, 1973). Results were expressed as the mean \pm SE for six measures. Significance was considered at a level of $\mathrm{P}<0.05$.

\section{Results}

The effects of the herbicide gallant, or the heavy metal, mercury or the combination of both toxicants on GOT \& GPT activities showed a significant progressive decrease when compared with the control values throughout the periods of exposure. Mercury solitary decreased the GOT activity more than the other treatments (Table 1); while the GPT activity was largely affected by mercury and gallant combination (Table 2). Similar results were obtained by Oser (1965), Street (1970), Krample (1971), El-Elaimy (1981) and Asztalos et al., (1988). They attributed this reduction to hepatocellular damage.

The hepatic total protein content was significantly decreased during all the periods of experiment, except at 6 and 12 hrs intervals of exposure (mercury and gallant separately) they were both insignificant (Table 3). Similar decreases in total proteins were found with pesticides in rats (Choudhari and Chakrabarti, 1983); in cockerels (Mohiuddin and Ahmed, 1986); in pigeons and chickens (Khalifa et al., 1989; Saleh et al., 1991) and in fishes Bansal et al., 1979).

The effect of all treated pollutants on hepatosomatic index of fish showed a slight insignificant increase with exception to the significant decrease during the last two intervals of exposure to mercury \& gallant combination and the significant increase at the last period of exposure to gallant alone (Table 4). 


\section{Abdel-Salam Mohamed Ibraik Ohaida}

Table 1: Liver glutmamic oxaloacetic transminase (GOT) activity (U/g wet tissue) of different fish groups.

\begin{tabular}{|l|c|c|c|c|c|l|}
\hline \multirow{2}{*}{ Experimental groups } & \multicolumn{5}{|c|}{ Duration in hours } \\
\cline { 2 - 7 } & $6 \mathrm{~h}$. & $12 \mathrm{~h}$. & $24 \mathrm{~h}$. & $48 \mathrm{~h}$. & $72 \mathrm{~h}$. & $96 \mathrm{~h}$. \\
\hline Control & $149.82 \pm 5.51$ & $149.49 \pm 6.53$ & $151.49 \pm 3.48$ & $147.82 \pm 8.05$ & $148.66 \pm 6.97$ & $141.66 \pm 7.07$ \\
\hline Herbicide gallant & $55.42 \pm 2.21^{*}$ & $58.07 \pm 3.10^{*}$ & $59.67 \pm 0.91^{*}$ & $61.82 \pm 3.24^{*}$ & $64.00 \pm 2.58^{*}$ & $65.78 \pm 2.30^{*}$ \\
\hline Mercuric chloride & $46.25 \pm 1.06^{*}$ & $50.25 \pm 2.60^{*}$ & $51.32 \pm 1.15^{*}$ & $40.24 \pm 1.35^{*}$ & $38.92 \pm 1.73^{*}$ & $25.57 \pm 2.02^{*}$ \\
\hline Gallant+ mercuric chloride & $60.16 \pm 2.66^{*}$ & $65.24 \pm 4.14^{*}$ & $61.49 \pm 4.01^{*}$ & $67.24 \pm 2.45^{*}$ & $67.74 \pm 2.13^{*}$ & $51.07 \pm 1.50^{*}$ \\
\hline
\end{tabular}

All results are expressed as mean $\pm \mathrm{SE}$ of six fishes.

- $\quad$ statistically significant $(\mathrm{P}<0.05)$

Table 2: Liver glutamic pyruvic transminase (GPT) activity (U/g wet tissue) of different fish groups.

\begin{tabular}{|l|c|c|c|c|c|c|}
\hline \multirow{2}{*}{ Experimental groups } & \multicolumn{6}{c|}{ Duration in hours } \\
\cline { 2 - 7 } & 6h. & $12 \mathrm{~h}$. & $24 \mathrm{~h}$. & $48 \mathrm{~h}$. & $72 \mathrm{~h}$. & $96 \mathrm{~h}$. \\
\hline Control & $137.74 \pm 2.98$ & $138.49 \pm 2,59$ & $140.67 \pm 0.88$ & $140.32 \pm 2.47$ & $143.33 \pm 3.72$ & $143.49 \pm 2.84$ \\
\hline Herbicide gallant & $24.01 \pm 1.66^{*}$ & $30.01 \pm 1.66^{*}$ & $49.82 \pm 0.40^{*}$ & $55.02 \pm 2.41^{*}$ & $59.01 \pm 4.07^{*}$ & $62.32 \pm 3.65^{*}$ \\
\hline Mercuric chloride & $15.01 \pm 2.03^{*}$ & $26.50 \pm 3.05^{*}$ & $28.16 \pm 1.39^{*}$ & $60.65 \pm 3.65^{*}$ & $49.01 \pm 3.53^{*}$ & $37.32 \pm 2.80^{*}$ \\
\hline Gallant+ mercuric chloride & $36.49 \pm 4.67^{*}$ & $32.32 \pm 4.18^{*}$ & $28.19 \pm 0.75^{*}$ & $17.32 \pm 2.54^{*}$ & $16.49 \pm 1.01^{*}$ & $12.32 \pm 0.75^{*}$ \\
\hline
\end{tabular}

All results are expressed as mean \pm SE of six fishes.

* statistically significant $(\mathrm{P}<0.05)$

Table 3: Liver total protein content (mg/g wet tissue) of different fish groups.

\begin{tabular}{|l|c|c|c|c|c|c|}
\hline \multirow{2}{*}{ Experimental groups } & \multicolumn{6}{|c|}{ Duration in hours } \\
\cline { 2 - 7 } & $6 \mathrm{~h}$. & $12 \mathrm{~h}$. & $24 \mathrm{~h}$. & $48 \mathrm{~h}$. & $72 \mathrm{~h}$. & $96 \mathrm{~h}$. \\
\hline Control & $189 \pm 9.5$ & $180 \pm 10.0$ & $170 \pm 6.3$ & $180 \pm 9.8$ & $180 \pm 9.7$ & $170 \pm 8.2$ \\
\hline Herbicide gallant & $190 \pm 8.6$ & $150 \pm 18.0$ & $130 \pm 10.0^{*}$ & $130 \pm 3.3^{*}$ & $120 \pm 20.0^{*}$ & $50 \pm 5,6^{*}$ \\
\hline Mercuric chloride & $170 \pm 15.0$ & $140 \pm 24.0$ & $60 \pm 4.7^{*}$ & $50 \pm 5.6^{*}$ & $50 \pm 6.1^{*}$ & $50 \pm 5.3^{*}$ \\
\hline Gallant+ mercuric chloride & $100 \pm 8.5^{*}$ & $60 \pm 5.5^{*}$ & $80 \pm 12^{*}$ & $110 \pm 12.0^{*}$ & $60 \pm 8.9^{*}$ & $50 \pm 5.6^{*}$ \\
\hline
\end{tabular}

All results are expressed as mean \pm SE of six fishes.

* statistically significant $(\mathrm{P}<0.05)$

Table 4: Hepatosomatic index (HSI) of different fish groups.

\begin{tabular}{|c|c|c|c|c|c|c|}
\hline \multirow[t]{2}{*}{ Experimental groups } & \multicolumn{6}{|c|}{ Duration in hours } \\
\hline & $6 \mathrm{~h}$. & $12 \mathrm{~h}$. & $24 \mathrm{~h}$. & $48 \mathrm{~h}$. & $72 \mathrm{~h}$. & $96 \mathrm{~h}$. \\
\hline Control & $\begin{array}{c}0.9968 \\
+0.0874\end{array}$ & $\begin{array}{r}1.3096 \\
+0.1319\end{array}$ & $\begin{array}{c}1.2579 \\
+0.1439\end{array}$ & $\begin{array}{c}0.9351 \\
+0.0653\end{array}$ & $\begin{array}{c}1.1074 \\
+0.0672\end{array}$ & $\begin{array}{r}0.9899 \\
+0.0385\end{array}$ \\
\hline Herbicide gallant & $\begin{array}{c}1.0574 \\
\pm 0.0949\end{array}$ & $\begin{array}{c}1.0690 \\
\pm 0.1473\end{array}$ & $\begin{array}{c}1.2202 \\
\pm 0.0752\end{array}$ & $\begin{array}{c}1.1524 \\
\pm 0.2037\end{array}$ & $\begin{array}{c}1.236 \\
\pm 0.0824\end{array}$ & $\begin{array}{l}1.2351 * \\
\pm 0.0824\end{array}$ \\
\hline Mercuric chloride & $\begin{array}{c}1.1766 \\
\pm 0.2279\end{array}$ & $\begin{array}{c}1.0336 \\
\pm 0.1670\end{array}$ & $\begin{array}{c}1.2364 \\
\pm 0.1801 \\
\end{array}$ & $\begin{array}{c}1.2157 \\
\pm 0.1884 \\
\end{array}$ & $\begin{array}{c}1.2626 \\
\pm 0.1466 \\
\end{array}$ & $\begin{array}{r}1.1089 \\
\pm 0.0441\end{array}$ \\
\hline Gallant+ mercuric chloride & $\begin{array}{r}1.2034 \quad * \\
\pm 0.0116\end{array}$ & $\begin{array}{l}1.4949 \\
\pm 1.408\end{array}$ & $\begin{array}{c}1.1575 \\
\pm 0.1937\end{array}$ & $\begin{array}{c}0.9291 \\
\pm 0.1142\end{array}$ & $\begin{array}{c}0.7994 \quad * \\
\pm 0.0599\end{array}$ & $\begin{array}{l}0.8561 * \\
\pm 0.0405\end{array}$ \\
\hline
\end{tabular}

All results are expressed as mean $\pm \mathrm{SE}$ of six fishes.

statistically significant $(\mathrm{P}<0.05)$ 


\section{Discussion}

The severe reduction in GOT \& GPT activity in the liver of the treated fishes with mercury alone or the combination between mercury \& gallant could be attributed to the high accumulation of mercury in the liver of fish (Saleh 1982 and Mazhar et al., 1986b). The last author demonstrated that, liver damage was proved by aggregations of RBCs, dilatation and congestion of blood vessels. Hepatocellular degeneration progressed to vacuolar necrosis with inflammatory and haemorrhagic lesions. This was accompanied by anastomosis of hepatic circulation and increase in Kupffer cells

The herbicide and heavy metals caused a destructive effect on the lysosomal membranes of the liver cells, followed by a release of proteases and other protein splitting enzymes, which destroyed some important intracellular proteins, but did not convert them into their amino acid components. Meanwhile, there might have occurred an increased uptake of selective amino acids from the liver to rebuild these compounds for the repair processes of cells, thus accounting for the decrease in the protein content in liver of treated fishes. Previous results of earlier workers corrolate with this explanation (Awasthi et al., 1984).

The importance of the transamination system lies not only in the breakdown of amino acid, but also in their biosynthesis. Thereby a direct relationship existed between the liver GOT and GPT activities and total protein content during the present study.

The slight increase in HSI values in the present data was referred to the accumulation of pollutants as suggested by many authors (Kendall, 1977 and Mazhar et al., 1986a, b).

Saleh (1982) reported that, the pollution of the aquatic environment causes an increase in the hepatosomatic index. This probably means that the HSI could be used as a quick indicator for detecting pollution in the aquatic environments. As a matter of fact, the amount of pollutants in the fish liver is directly proportional to the degree of pollution in the aquatic environment by heavy metals and pesticides. Accordingly, the hepatosomatic index may be considered as a valid indicator for this type of pollution.

\section{References}

1. Asztalos B, Nemcsok J, Benedeczky I, Gambriel $R$ and Szabo $A$ (1988): Comparison of effects of paraquat and methidation on enzyme activity and tissue necrosis of carp following exposure to the pesticides singly or in combination. Environm. Pollut., 55(2): 123-136.

2. Awasthi M, Shah $\mathbf{P}$, Dubale MS and Gndhia P (1984): Metabolic changes induced by organophosphates in the piscine organs. Environm. Res., 35: 320325.

3. Bansal SK, Verma SR, Gupta AK and Dalela RC (1979): Physiological dysfunction of the haemopoietic system in a fresh water Teleost, Labeo rohita, following chronic chlordane exposure. Part II Alterations in certain organic components and serum electrolytes. Buli. Environm. Contam. Toxicol., 22: 674680.

4. Cabib E and Polacheck I (1984): "Protein assay for dilute solutions". Methods in Enzymology, 104: 318-328.

5. Cashman JR, Olsen LD, Nishioka RS, Gray ES and Bern HA (1990): SOxygenation of thiobencarp bolero in hepatic preparations from striped bass Morone saxatilis and mammalian system. Chemical Research in Toxicology, 3(5): 433-440.

6. Choudhari PD and Chakrabarti $\mathbf{C H}$ (1983): Effects of isofenphos (oftanol) and acephate (orthene) on fecal bile acids, cholesterol and protein content of serum and liver in albino rats. Indian J. Exp. Biol., $21: 684-685$.

7. Dalton MS and Frick EA (2008): Fate and transport of pesticides in the ground water systems of southwest Georgia, 1993-2005. J Environ Qual., 37 (5): s 26472.

8. El-Elaimy IA (1981): Physiological and biochemical studies on the effect of three insecticides, Temik, Decamethrin, and Dimethoate on mammals. Ph. D. thesis, Zoology Department, Faculty of Science, Assiut University, Aswan, Egypt.

9. Jangaard PM, Ackman RG and Sipos JC (1967): Seasonal studies of the fatty acid composition of cod liver, flesh, roe 


\section{Abdel-Salam Mohamed Ibraik Ohaida}

and milt lipids. J. Fish Res. Bd. of Canada, 24(2): 613-627.

10. Kendall MW (1977): Acute effects of methyl mercury toxicity in channel catfish Ictalurus punctatus liver. Bul. Environ. Contam. Toxicol., 18: 143-151.

11. Khalifa MH, Saleh F, El-Saify and ElShater AA (1989): Effects of the insecticide dipterex on serum proteins of two Egyptian birds. Bull. Fac. Sci., Cairo Univ., 57: 193-204.

12. Krample V (1971): Relationship between serum enzymes and histological changes in liver after administration of hepatochlor in the rat. Bull. Environ. Contam. Toxicol., 5: 529-538.

13. Matsumura F (1975): Mode of action of insecticides, In: Toxicology of insecticides, p. 142, New York: Plenum Press.

14. Mazhar FM, Ashry MA and Kadry SM (1986a): The accumulation of inorganic mercury by the freshwater catfish Clarias lazera Proc. Zool. Soc. A. R. Egypt, 12: 59-73.

15. Mazhar FM, Ashry MA and Kadry SM (1986b): Effects of environmental pollution on the histological features of the major organs of the Nile catfish Clarias lazera Proc. Zool. Soc. A. R. Egypt, 12: 75-89.

16. Mohiuddin SM and Ahmed MN (1986): Effect of feeding Ekalux (Quinolphs) pesticide in poultry. Indian Veter. J., 63: 796-798.

17. Oser BR (1965): In Hawks physiological chemistry $14^{\text {th }}$ ed. The Blakiston Division. Mc-Graw Hill Book, New York, 1126 pp.
18. Parker RE (1973): Introductory statistics for biology. Edward Arnold., 22pp.

19. Portmann JE (1972): The level of certain metals in fish from coastal waters around England and Wales. J. Aguacuiture, 1: 9195.

20. Riviere JL, Devaux A, Conin O And Monod G (1990): Effect of beta naphthoflavone and MCPA on liver and kidney drug-metabolizing enzymes from the carp Cyprinus carpio. Ecotoxicol. Environ. Saf., 19(3): 276-284.

21. Sabath LD, Gerstein DA and Finland M(1968): GOT/GPT procedures: Intended for the quantitative determination of glutamic-oxalacetic and glutamic-pyruvic transaminases in serum using a colorimetric method. New Eng J Med, 21:1137.

22. Saleh HH (1982): Fish liver as indicator of aquatic environmental pollution. Bull. Inst. Oceanogr. and Fish. A. R. E., 8(1): 69-79.

23. Saeh F, Abdel-Raheem AE and Eslam NN (1991): Effect of synthetic pyretthroid cypermethrin on protein metabolism in pigeon. J. Egypt. Ger. Soc. Zool., 3 : 6373.

24. Scott DP and Armstrong FA (1972): Mercury concentration in relation to size in several species of fresh water fishes from Monitoba and North Western Ontario. J. Fish. Res., Bd. Canada, 29: 1985-1690.

25. Street AS (1970): Comparison of selected parameters for monitoring methoxychlor induced hepatoxicity. Bull. Environ. Contam., Toxicol. 23: 275-280. 


\section{تأثير مبيد الحشائش جالتت والزئبق على وظائف الكبا للسمكة البلطي من نوع Tilapia zillii}

\section{عبد السلام محمد ابريك اوحيده}

قسم علم الحيوان ـ كلية العلوم- جامعة السابع من أكتوبر - مصرتةـ ليبيا

لقد صممت هذه الدراسة لفحص التأثير السام لمبيد الحشائش جالنت وكذلك كلوريد

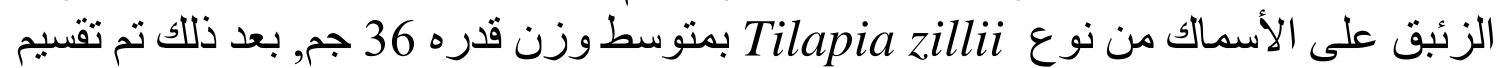

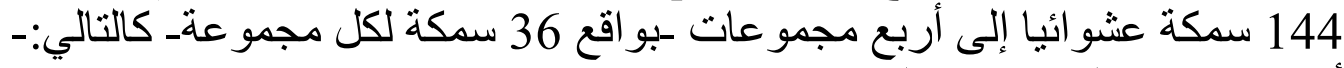
أ - مجمو عة طبيعية ضابطة.

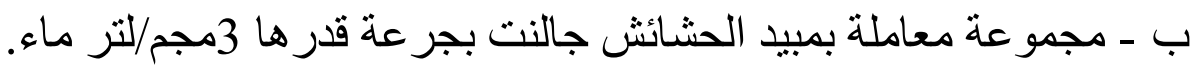

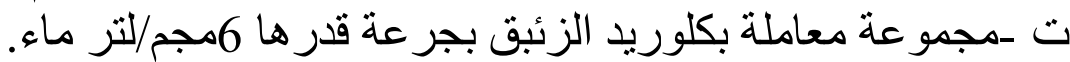

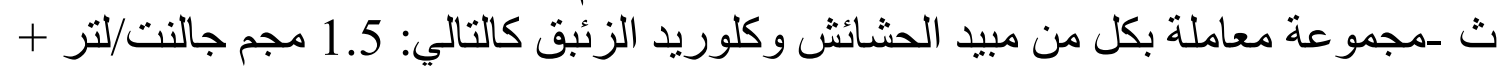
3مجم من كلوريد الزئبق/لتر ماء.

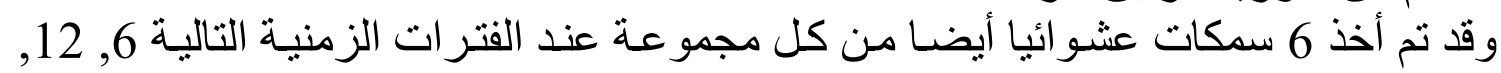

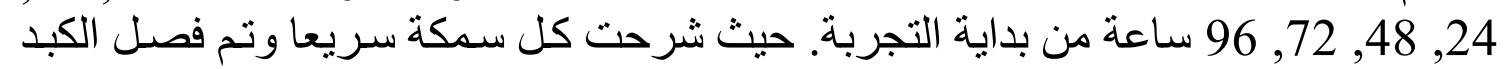

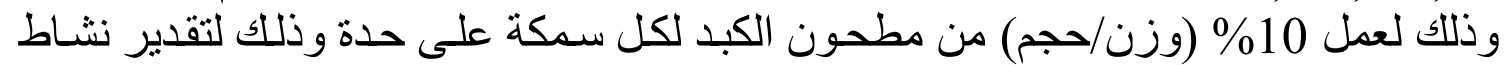
إنزيمات التز انس امينيز GOT , GPT بالإضافة إلى المحتوى البروتين الكلى للكبد.

$$
\text { ولقد خلصت الدر اسة الحالية على الأتى:- }
$$

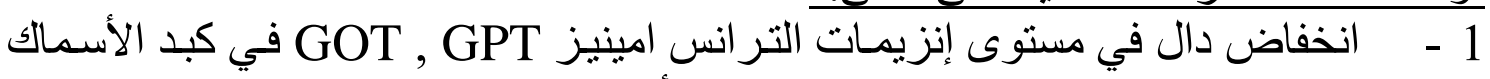

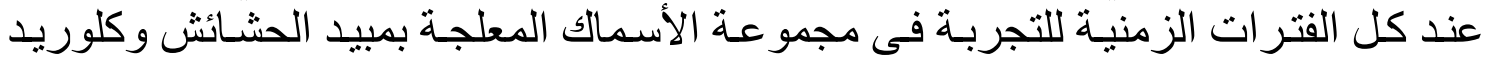

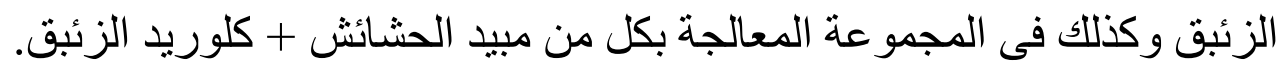

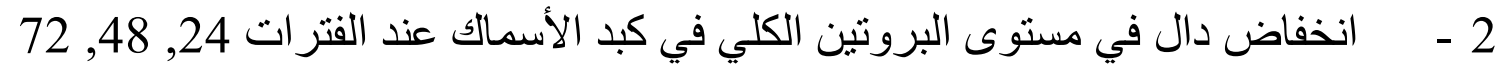
و 96 ساعة بينما كان الانخفاض غير معنوى عند الفترتين 6, 12 ساعة في كل الإن المجموعات

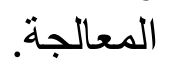

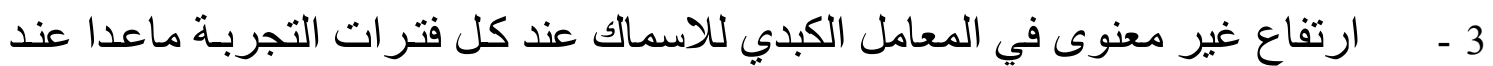

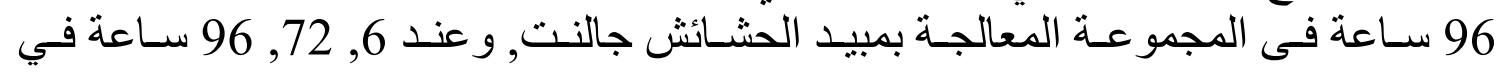
المجموعة المعالجة بكل من مبيد الحشائش + كلوريد الزئبق فقد كان الارتفاع معنويا. 